\title{
INFLUENCE OF TAX COMPLIANCE COST ON HOSTEL OWNERS' COMPLIANCE TO RENTAL INCOME TAX IN LAIKIPIA WEST SUB COUNTY, KENYA
}

\author{
Denis Brian Gichuru' ${ }^{1 \mathrm{i}}$, \\ John N. Wahome ${ }^{2}$ \\ ${ }^{1}$ Laikipia University, \\ Main Campus, P. O. Box 1100-20300, \\ Nyahururu, Kenya \\ ${ }^{2}$ Senior Lecturer, \\ School of Science and Applied Technology \\ Laikipia University, \\ Main Campus, P. O. Box 1100-20300, \\ Nyahururu, Kenya
}

\begin{abstract}
:
The Government of Kenya through the Finance Act 2015 introduced a simplified rental income tax. This is a monthly tax payable by a resident person for rental income earned from use or occupation of residential property. Upon the gazettement of the Income Tax (Residential Rental Income Tax) Regulations, 2016, the Kenya Revenue Authority embarked on an aggressive campaign to enlist landlords into the Monthly Rental Income Tax regime. However, the Economic Survey 2021 showed that the country's revenue collecting agency KRA was not able to meet revenue targets as set by the National Treasury. Comparison of National Government Budget Estimates with Actual Out turns for the fiscal years 2017/2018 and 2018/2019 showed that KRA missed the Budgeted Ordinary Revenue targets by Kshs.128.7 Billion and Kshs.90.1 Billion respectively. Property taxes including rental income tax are part of the ordinary revenue collected by the tax authority. The objective of the study was to investigate the influence of tax compliance cost on hostel owners' compliance to the monthly rental income tax in Laikipia West Sub County. Quantitative data was collected using questionnaires. A census of the entire population of hostels was used to collect the required data. The collected data was analysed using the Statistical Package for Social Sciences (SPSS). The study established that an increase in tax compliance cost discourages compliance behavior since taxpayers tend to evade the costs either by under-declaring their monthly rental incomes or not declaring any income at all. The study recommends that KRA should scale up the tax payer education and awareness programs to ensure that more
\end{abstract}

i Correspondence: email churr78@gmail.com, jwahomestead@gmail.com 
landlords are trained on how to file their own returns without having to use tax agents who make the process costly leading to non-compliance.

JEL: H25, H26

Keywords: tax, tax compliance, tax compliance cost

\section{Introduction}

Taxation and tax compliance is a matter that is as old as mankind. In the Holy Scriptures, Jesus Christ instructed his disciples to pay taxes to the authorities using the famous words: give to Caesar what belongs to Caesar and to God what belongs to God. Tax Compliance can be expounded and explained as the degree to which a taxpayer complies with or fails to comply with tax laws, tax policies and tax regulations of a country in which he is a resident. A taxpayer can be an individual, a body corporate, a partnership or a business formation. Tax compliance entails the declaration of all income earned in a particular tax period, filing of a tax return and paying all the taxes due within the stipulated timelines. Tax evasion on the other hand can be defined as the willful failure by a person or business to comply with their tax obligations. Tax evasion poses serious challenges to tax authorities in both the developed and developing countries since in most cases it is also linked to other serious crimes such as sale of narcotics, human trafficking, terrorism financing amongst others. Tax evasion denies a nation the most needed financial capital and diminishes the mobilization of resources that governments need to invest in critical areas of social and personal development including health, education and infrastructure development (Cummings, 2007).

All over the world, the question of how to increase tax compliance is a growing concern for all governments both in the developed and developing countries (Frey \& Weck-Hannemann, 1984). Tax noncompliance is a very widespread challenge that costs governments, and thus its citizens, billions of dollars each year. In the context of the United States (U.S.), tax non-compliance is believed to cost the federal government over $\$ 300$ billion annually (http://www.irs.gov). However, the traditional economic models of tax compliance, which primarily focus on the implementation of enforcement measures and detection variables, are unable to explain current levels of compliance. Evidence from data collected in the U.S. shows that public opinion and public attitude toward tax cheating and tax avoidance is becoming more lax. A recent survey conducted in the U.S showed that the proportion of people who believed it was "every American's civic duty to pay his fair share of taxes" was only 68\%, compared to $81 \%$ in 1999 (Dalrymple, 2003). Thus, to the extent that we can identify the antecedents of these attitudes, new strategies to address non-compliance can be developed (Bobek, Roberts \& Sweeny, 2007).

Taxation is one major source of government revenue in Kenya and according to IEA (2012) it funds approximately $60 \%$ of government total expenditure. The magnitude of the total revenue generated from taxation has made tax reforms a key ingredient to 
various fiscal policies especially in the area of deficit financing. Apart from raising revenue, other core objectives of tax system are redistribution of wealth or income and to encourage or discourage certain activities through the use of tax provisions However, in many countries saddled in fiscal deficit phenomenon, revenue generation overrides the other functions (Gituku, 2011). Issues of taxation and development (e.g., tax reform, tax base, tax administration, tax evasion, informality, and taxation) are gaining renewed and increasing interest both from academic and policy circles (Keen, 2012).

\section{Statement of the Problem}

Although the real estate sector in Kenya has continued to register tremendous growth over the years, the revenue that KRA has been collecting has not been commensurate with that growth and as a result, the KRA launched an aggressive tax compliance campaign in July 2012 with an aim of increasing tax revenues. In 2015 KRA sought to encourage 20,000 landlords to join the tax net with an aim of collecting at least Kenya Shillings 3 Billion. For the fiscal years 2017/2018 and 2018/2019, the KRA was not able to meet the revenue collection targets as set by the National Treasury. Comparison of National Government Budget Estimates with Actual Out - turns for the fiscal years 2017/2018 and 2018/2019 showed that KRA missed the Budgeted Ordinary Revenue targets by Kshs.128.7 Billion and Kshs.90.1 Billion respectively. One of the reasons that can be directly attributed to KRA not meeting the revenue collection target could be the non compliance by landlords and developers with the requirement to pay the 10 per cent monthly rental income tax. This study therefore, endeavored to examine the influence of tax compliance cost on hostel owners' compliance with the monthly rental income tax in Laikipia West Sub County. Tax compliance was measured using the number of taxpayers who file the monthly rental income tax return and pay the associated taxes arising therefrom.

\section{Literature Review}

Jackson and Milliron (1986) in their seminal work critically reviewed fourteen variables that impact on taxpayer compliance. These were: age, gender, income level, income source, occupation, peer influence, ethics, fairness, complexity, revenue authority contact, sanctions and probability of detection. In this study, the researchers adopted the definition of a compliant taxpayer as one who files an 'accurate, timely and fully paid return without IRS enforcement efforts. Although this definition allows for both intentional and unintentional compliance, it does not clarify whether the taking of an aggressive tax position on an ambiguous issue represents non-compliance if the revenue authority or the courts fail to accept the treatment at a later date (Richardson \& Sawyer, 2001).

Fischer et al., (1992) further categorized Jackson and Milliron's variables into 4 groups: (i) demographic (e.g. - age, gender and education) (ii) noncompliance 
opportunity (e.g. income level, income source and occupation), (iii) attitudes and perceptions (e.g. fairness of the tax system and peer influence) and (iv) tax system/structure (e.g. complexity of the tax system, probability of detection and penalties and tax rates). Thus, Fischer's model of tax compliance incorporates economic, sociological and psychological factors into a comprehensive one (Chau \& Leung, 2009).

McKerchar and Evans (2009) developed the theory of reasoned action in which they postulated that individuals form their behaviour intentions on the bases of two basic determinants - personal factors and social influences. They further argued that social psychology models are concerned with the prediction and understanding of human behaviour or how people make decisions using a range of methodological approaches including compositional modeling, attribution theory and equity theory. Franzoni (1999) concludes that social and moral attitudes play a very important role in determining tax compliance but are very slow to change and are often beyond the reach of public policy. Someone's personal norms or morale with respect to rules and regulations does not develop overnight. Personal norms are rooted in core values and develop as a result of long-term socialization processes

Individuals, households, incorporated businesses, sole proprietorships, and other business formations interact with the tax authority in their jurisdictions as taxpayers and must as a necessity comply with convoluted tax laws, tax policies, and tax regulations and they find themselves weighed down with tax compliance matters that continue to increase in complexity (Eichfelder \& Vaillancourt, 2014).

Public finance and economic literature has deeply delved into the discussion on the complexity of taxation (Alm, 1996; Kaplow, 1996; Slemlord, 1996; Slemrod \& Yitzaki, 1996; Slemrod \& Yitzaki, 2002). Complexity of tax laws has serious ramifications in terms of equity and efficiency in taxation. When contemplated from an efficiency viewpoint, costly tax compliance activities can be regarded as a squander of scarce economic resources because they tend to lead to an enlargement of the tax burden as well as an increase in the cost of doing business without a corresponding increase in government revenue (Eichfelder \& Vaillancourt, 2014).

A great deal of the literature dealing with tax compliance costs and the complexity of tax laws has predominantly focused on: the impact of rationalization of tax laws; causes of tax law complexity; measurement of complexity of tax laws; effect of such complexity on tax compliance costs; and the estimation of tax compliance costs (Evans, 2003; Cuccia \& Cannes, 2001; Forest \& Sheffrin, 2002). So far, however, little attention has been paid to the impact of tax compliance costs on tax compliance behaviour, particularly in the context of property owners operating hostel businesses in Kenya. Complexity in tax laws and tax compliance costs are positively interlinked (Evans, 2003).

Slemrod and Venkatesh (2002) backed by empirical evidence argue that the economic burden of tax compliance reduces as the business unit expands its operations and it rises when the taxpayer adopts an international outlook. Economic decision making as well as the optimal allocation of resources could be distorted by rising compliance costs (Eichfelder \& Vaillancourt, 2014). Djankov et al. (2002) further posit that 
the increased burden of compliance to tax law may hinder the development and growth of micro, small and medium enterprises (MSMEs) as well as reduce the number of business startups.

In Kenya, accounting for excise taxes for those firms dealing with the manufacture and supply of excisable goods and services may be relevant cost especially after the KRA instituted the Excisable Goods Management System. Non-economic costs include the psychological costs of stress and anxiety arising from complying with a specific tax or from a tax-related activity, such as a tax authority audit. The existence of such noneconomic costs is recognized although it is usually ignored (Pope, 2012). In this study, the influence of tax compliance cost on tax compliance behaviour will be proxied using the cost of filing returns; the cost of hiring a tax agent; other incidental costs associated with filing returns; and the cost of training on how to file the returns.

The compliance costs of taxation comprise both economic and non-economic costs. The economic costs, which may be estimated, consist of the monetary and time costs in dealing with the requirements of the tax authorities (Pope, 2002). Tax compliance costs are typically represented by the cost of bookkeeping, tax accounting, tax return preparation, tax planning and post filing activities such as cost associated with amending returns, tax audit consultation, tax appeal representation and tax litigation legal costs. For individuals, compliance costs include the cost of time spent by a taxpayer on recordkeeping and completing the tax form or in preparing information for a tax agent or accountant; the fees paid to a professional adviser, such as a tax agent; and miscellaneous costs, such as postage, phone calls, taxation guides, and, increasingly, computer software. For business taxation, the costs include the monetary costs spent on the professional fees of tax agents, accountants, lawyers, and any other advisers; and the time costs of internal staff on maintaining tax information throughout the year; completing the tax returns themselves or in preparing information for professional advisers and dealing with the tax authorities. Businesses also have to grapple with the intricacies of accounting for income tax, corporation taxes, Value Added Tax (VAT), withholding taxes on staff emoluments. Accounting for import duties also represents a relevant compliance cost for individuals and firms engaged in the importation of goods (Eichfelder \& Vaillancourt, 2014).

Jemaiyo and Mutai (2016) assessed determinants of tax compliance and their influence on the level of tax compliance in the real estate sector, Eldoret town in Kenya. Using ex-post facto research design, the study targeted a population of 605 . A sample size of 68 respondents comprising of real estate investors, tax audit and tax compliance officers were drawn from the target population using snowball sampling and purposive sampling methods. Data was collected using a structured questionnaire. This study found out that tax compliance cost, tax knowledge, tax penalties and tax audit had significant effect on level of tax compliance. High tax compliance costs were a contributing factor that reduced tax compliance among real estate investors. The study thus recommended that tax compliance cost should be as minimal as possible to encourage payment of income tax. It additionally suggested that there should be 
continual training of tax payers in the real estate sector in order ensure that they are aware and practice tax laws put in place. The research further recommended tax penalties laws and tax audit should be implemented and take place to encourage payment of taxes by the real estate investors.

\section{Materials and Methods}

This study adopted a census research design. A census eliminates sampling error and provides data on all the individuals in the population (Cochran, 1963). The target population of this research was the owners of the fourty privately run hostels serving the Laikipia University student community that resides off campus. These hostels had been inspected and approved by the Laikipia West Sub County Public Health Officer and Laikipia University Halls Department. In this particular study, the sampling frame was the list of the owners of the forty privately run hostels who have registered with the Laikipia University Hostel Owners Association. Data for this study was collected using questionnaires administered to all the targeted respondents. Dempsey (2003) posits that questionnaires are the preferred tools for effective data collection since they allow the respondents to proffer their honest opinions on the subject matter being studied. The data obtained was subjected to both descriptive and quantitative data analysis. Descriptive data analysis was conducted so as to determine the totals, percentages and mean of the dependent and independent variables and the data analysis results were presented in form of tables.

Quantitative data analysis involved the conduct of Analysis of Variance (ANOVA), correlation analysis and regression analysis on the data set. The researcher also performed correlational analysis between each independent variable and the dependent variable separately to determine whether a relationship exists and how strong it might be. Quantitative data analysis was performed with the aid of the Statistical Program for Social Sciences (SPSS).

The regression equation took the following form:

$T C=\alpha+\beta_{1} T C C_{1}+\varepsilon_{t}$

Where:

$\mathrm{TC}=$ measure of tax compliance

$\alpha=$ Constant

$\beta_{1,}=$ Coefficients of the regressor variables

$\mathrm{TCC}_{1}=$ tax compliance cost

$\varepsilon_{\mathrm{t}}=$ error term 


\section{Results and Discussion}

\subsection{Descriptive Statistics}

The respondents were given a structured questionnaire with Likert type questions in which they were to pick one response per question statement using the Likert scale of 15, where 1 represented strongly agree and 5 represented strongly disagree. The descriptive statistics in the form percentages and arithmetic means were presented in a tabular form as shown in Table 1.

Table 1: Tax Compliance Cost $(\mathrm{N}=37)$

\begin{tabular}{|l|c|c|c|c|c|c|}
\hline Construct/Responses & $\begin{array}{c}\text { VL } \\
\mathbf{( \% )}\end{array}$ & $\begin{array}{c}\mathbf{L} \\
\mathbf{( \% )}\end{array}$ & $\begin{array}{c}\mathbf{F} \\
\mathbf{( \% )}\end{array}$ & $\begin{array}{c}\mathbf{H} \\
\mathbf{( \% )}\end{array}$ & $\begin{array}{c}\text { VH } \\
(\%)\end{array}$ & $\begin{array}{c}\text { Likert } \\
\text { Mean }\end{array}$ \\
\hline $\begin{array}{l}\text { How do you rate the cost of filing the monthly rental } \\
\text { income tax return? }\end{array}$ & 5.6 & 10.5 & 8.5 & 33.6 & 41.8 & 3.955 \\
\hline $\begin{array}{l}\text { How do you rate the cost of hiring a tax agent to file the } \\
\text { monthly rental income tax return on your behalf? }\end{array}$ & 5.8 & 12 & 5.1 & 26.9 & 50.2 & 4.037 \\
\hline $\begin{array}{l}\text { How do you rate other incidental costs associated with } \\
\text { filing of the tax return such as travelling costs, airtime? }\end{array}$ & 25.0 & 11.0 & 25.4 & 5.5 & 33.1 & 3.107 \\
\hline $\begin{array}{l}\text { How do you rate the cost of being trained on how to file } \\
\text { the return by external parties such as cybercafé operators } \\
\text { or private accountants? }\end{array}$ & 6.8 & 13.9 & 10.9 & 31.9 & 36.0 & 3.749 \\
\hline
\end{tabular}

Key: 1=Very Low, 2=Low, 3=Fair, 4=High, 5=Very High

The objective of the study sought to determine how tax compliance cost influences hostel owners' compliance to rental income tax in Laikipia West Sub County. The objective was tested through five (5) composite measures on a scaled questionnaire. The findings are presented in Table 1 which shows frequencies of responses and mean on the influence of tax compliance cost on tax compliance of hostel owners in Laikipia West Sub County, Kenya.

The majority of the respondents at $41.8 \%$ rated the tax compliance cost as being very high and a hindrance in achieving compliance behavior among hostel owners with a mean of 3.955. Similarly, hostel owners stated that the cost of hiring competent tax agents to carry out the task was very high at $50.2 \%$ with a mean of 4.037 . On the other incidental costs associated with filing of tax returns, the respondents said the cost was very high at $33.1 \%$ with a mean of 3.107 . The study sought to determine the respondents' opinion on the cost of being trained on how to file income tax returns and $36 \%$ of the respondents said the training cost as very high while $31.9 \%$ stated it was high.

\subsection{Test for Normality}

The dependent and independent variables were tested for normality using the Kolmogorov-Smirnov test. If the p-value exceeds $\alpha$-value of 0.05 then the data is normal. The $\alpha$-values for the independent variable - Tax Compliance Cost was 0.058 while that of the dependent variable - Tax Compliance was 0.037 and all were above $\alpha$-value of 0.05 .

Therefore, all the variable data were normal as shown in Table 2. 
Table 2: Tests of Normality

\begin{tabular}{|l|c|c|c|}
\hline \multirow{2}{*}{} & \multicolumn{3}{|c|}{ Kolmogorov-Smirnov $^{\mathbf{a}}$} \\
\cline { 2 - 4 } & Statistic & $\mathbf{d f}$ & Sig. \\
\hline Tax Compliance Cost & .058 & 37 & .000 \\
\hline Tax Compliance & .037 & 37 & .000 \\
\hline
\end{tabular}

\subsection{Correlation Analysis}

This study sought to investigate the correlation between tax compliance cost and hostel owners' compliance to rental income tax in Laikipia West Sub County. Table 3 summarizes the correlation between these variables.

Table 3: Correlation between Tax Compliance Cost and Tax Compliance

\begin{tabular}{|l|l|c|c|}
\hline \multicolumn{2}{|l|}{} & Tax Compliance Cost & Tax Compliance \\
\hline \multirow{4}{*}{ Tax Compliance Cost } & Pearson correlation & 1 & $-.721^{* *}$ \\
\cline { 2 - 4 } & Sig (2-tail) & .000 & .000 \\
\cline { 2 - 4 } & $\mathrm{N}$ & 37 & 37 \\
\hline \multirow{3}{*}{ Tax Compliance } & Pearson correlation & $-.721^{* *}$ & 1 \\
\cline { 2 - 4 } & Sig (2-tail) & .000 & .000 \\
\cline { 2 - 4 } & $\mathrm{N}$ & 37 & 37 \\
\hline
\end{tabular}

Table 3 indicates a strong negative correlation between Tax Compliance Cost and Tax Compliance of hostel owners in Laikipia West Sub County. The Pearson's correlation coefficient is -0.721 which implies that when Tax Compliance Cost increases by a unit, Tax Compliance decreases by 0.721 units.

\subsection{Bivariate Regression Analysis on Tax Compliance Cost versus Tax Compliance 5.4.1 Model Summary}

Table 4: Model Summary

\begin{tabular}{|c|c|c|c|c|}
\hline Model & $\mathbf{R}$ & R Square & Adjusted R Square & Std Error of the Estimate \\
\hline 1 & $0.482^{a}$ & 0.232 & 0.231 & 0.764 \\
\hline
\end{tabular}

Bivariate regression analysis was done to establish the statistical significance of the influence of the independent variable - Tax Compliance Cost on the dependent variable -Tax Compliance. The results are as shown in table 4 above. As indicated in Table 4, the coefficient of determination $R$ square is 0.232 and $R$ is 0.482 at 0.05 significance level. The coefficient of determination indicates that $23.2 \%$ of the variations in tax compliance behavior of hostel owners with regard to payment monthly rental income tax is influenced by the associated tax compliance costs while $76.8 \%$ of the variations are explained by other factors which have not been considered by the model. 


\subsubsection{Bivariate Regression Co-efficients}

Table 5: Tax Compliance Cost and Tax Compliance

\begin{tabular}{|l|c|c|c|c|c|}
\hline Model & $\begin{array}{c}\text { Unstandardized } \\
\text { Coefficients Beta }\end{array}$ & $\begin{array}{c}\text { Std. } \\
\text { Error }\end{array}$ & $\begin{array}{c}\text { Standardized } \\
\text { Coefficients Beta }\end{array}$ & $\mathbf{t}$ & Sig. \\
\hline (Constant) & 1.975 & 0.185 & & 10.676 & $0.000^{\mathrm{a}}$ \\
\hline Tax Compliance Cost & $-.390^{* *}$ & 0.044 & 0.210 & -8.864 & 0.000 \\
\hline R & $.482^{\mathrm{a}}$ & & & & \\
\hline R Squared & .232 & & & & \\
\hline Adjusted R Squared & .231 & & & & \\
\hline Std. Error of the Estimate & .764 & \multicolumn{3}{|l|}{} \\
\hline NB: Dependent Variable: Tax Compliance. ${ }^{* *}$ means significant at 1\%. Predictor: (Constant), Tax Compliance Cost. \\
\hline
\end{tabular}

The researcher performed inferential analysis to ascertain the influence of tax compliance cost on the compliance behavior of hostel owners regarding monthly rental income tax in Laikipia West Sub County. Further, the linear relationship between Tax Compliance and Tax Compliance Cost can be expressed as:

$$
\begin{aligned}
& \mathrm{TC}=\beta_{0}+\beta_{1} \mathrm{TCC} \\
& \text { where } \beta_{0}=1.975 \text {, and } \\
& \beta_{1}=-0.390 \\
& \text { which can be modeled as follows: }
\end{aligned}
$$

$$
\mathrm{TC}=1.975-0.390 \mathrm{TCC}+\varepsilon .
$$

Therefore, a unit change in Tax Compliance Cost will result in a change of -0.39 in Tax Compliance which is significant at $1 \%$ implying an inverse relationship between tax compliance cost and taxpayer compliance.

\section{Conclusion and Recommendations}

The objective of the study was to examine the influence of tax compliance cost on hostel owners' compliance to rental income tax in Laikipia West Sub County. Using regression and correlation analysis, the study established that there is a significant negative relationship between tax compliance costs and tax compliance behaviour of hostel owners in the sub county. It became apparent from the results that as tax compliance costs increase, tax compliance levels decline. These results are congruent with the conclusions made by Jemaiyo and Mutai (2016) who found out that tax compliance costs had significant effect on level of tax compliance in the real estate sector.

From the findings of this study, tax compliance cost has statistically significant inverse influence on compliance behavior of hostel owners. An increase in tax compliance cost will discourage compliance behavior since taxpayers tend to evade the costs either by under-declaring their monthly rental incomes or not declaring at all. The findings 
suggest tax systems with low tax compliance costs are most likely to be complied with. Therefore, the tax compliance cost should be minimized to a level that does not encourage taxpayers to evade tax.

\title{
Conflict of Interest Statement
}

The authors declare no conflicts of interests.

\begin{abstract}
About the Authors
Denis Brian Gichuru is an Internal Auditor in the Department of Internal Audit at Laikipia University. He holds a Master of Business Administration (Finance) from Laikipia University, a Post Graduate Diploma in Tax Administration from Jomo Kenyatta University of Agriculture and Technology and a Bachelor of Arts (Economics) from Kenyatta University. His research interests include capital structure of Saccos and tax compliance of investors in the real estate sector in Kenya.

Dr. John Wahome is a Lecturer in the Department of Mathematics, Laikipia University, Kenya. He holds a PhD in Applied Mathematics from the University of Eldoret, Kenya and an M. Sc. (Applied Mathematics) from Egerton University, Kenya. His research areas include application of partial differential equations (PDE) in non-core-mathematics fields such as finance. He is currently the Director of Examinations and Timetabling at Laikipia University.
\end{abstract}

\section{References}

Cummings, R. G. (2007). Effect of tax morale on tax compliance. experimental and survey evidence. Working Paper Series, Centre for Research in Economics, Management and the Arts (CREMA).

Frey, B. \& J. Weck-Hannemann (1984). The Hidden Economy as an 'Unobserved' Variable, European Economic Review 26, 33-53.

Bobek, D., Roberts, R., \& Sweeney, J. (2007). The social norms of tax compliance: evidence from Australia, Singapore, and the United States. Journal of Business Ethics, 74(1), 49-64. Retrieved from http://www.jstor.org/stable/25075443

Chau, G. \& Leung, P. (2009). A critical review of Fischer tax compliance model: a research synthesis, Journal of Accounting and Taxation, 1 (2): 034 - 040.

Cochran, W. G. 1963. Sampling Techniques, 2nd Ed., New York: John Wiley and Sons, Inc.

Cuccia, A. D., \& Carnes, G. A. (2001). A closer look at the relation between tax complexity and tax equity perceptions. Journal of Economic Psychology, 22, 113-140.

Dalrymple, M. (2003). IRS worried that more taxpayers feel it's okay to cheat, Pittsburgh Post- Gazette October 30, 2003, C-11.

Dempsey, B. (2003). Research methods, (4th ed.). Pearson Publishers. 
Djankov, Simeon \& la porta, Rafael \& Shleifer, Andrei \& Lopez-de-Silanes, Florencio. (2002). The regulation of entry. The Quarterly Journal of Economics, 117, issue 1, $1-37$

Eichfelder, S., \& Vaillancourt, F. (2014). Tax compliance costs: A review of cost burdens and cost structures. Review of Public Economics, Vol. 210, Issue 3, 111-148.

Evans, C. (2003). Taxing personal capital gains: operating cost implication. Australian Tax Research Foundation, 2003

Fischer, C. M., Wartick, M. \& Mark, M. (1992). Detection probability and taxpayer compliance: a review of the literature. Journal of Accounting Literature. 11: 1- 46.

Forest, A., \& Sheffrin, S. M. (2002). Complexity and compliance: An empirical investigation. National Tax Journal, 55(1), 75-88

Franzoni, L. A. (1999). Tax evasion and tax compliance, Italy, University of Bologna, http://spazioweb.inwind.it/franzoni/papers/6020book.pdf

Gituku, F. G. (2011). Tax reforms and revenue productivity in Kenya. A Research Project submitted to the School of Economics for the Award of Master of Economics, University of Nairobi. Retrieved from www.erepository.uonbi.ac.ke, 29 $9^{\text {th }}$ November, 2018 at 8.00 A.M.

I.E.A (2012). A citizens' handbook of taxation in Kenya, Nairobi.

Jackson, B. R., Milliron, V.C. (1986). Tax compliance research: findings, problems, and prospects, J. Account. Lit. 5: 125-165.

Jemaiyo, B. \& Mutai, G. C. (2016). Determinants of tax compliance and their influence on the level of tax compliance in the real estate sector, Eldoret town - Kenya. African Peer Reviewed Journals, 12 (1), 555 - 584.

Keen, M. (2012). Taxation and development: Again. IMF Working Paper WP/12/220, Washington D.C

McKerchar, M. \& Evans, C. (2009). Sustaining growth in developing economies through improved taxpayer compliance: challenges for policy makers and revenue authorities. eJournal of Tax Research, 7, 171-201.

Pope, J. (2002). The administrative and compliance costs of international taxation: an introduction for research students.

Richardson, M. \& Sawyer, A. J. (2001). A taxonomy of the tax compliance literature: further findings, problems and prospects. Australian Tax Forum.

Slemrod, J. (2015). Tax compliance and enforcement: new research and its policy implications. Working draft prepared for the conference "The economics of tax policy".

Slemrod, J. B. \& Venkatesh, V. (2002). The income tax compliance cost of large and midsize businesses. Ross School of Business Paper No. 914. 
Authors will retain copyright to their published articles agreeing that a Creative Commons Attribution 4.0 International License (CC BY 4.0) terms will be applied to their work. Under the terms of this license, no permission is required from the author(s) or publisher for members of the community to copy, distribute, transmit or adapt the article content, providing a proper, prominent and unambiguous attribution to the authors in a manner that makes clear that the materials are being reused under permission of a Creative Commons License. Views, opinions and conclusions expressed in this research article are views, opinions and conclusions of the author(s). Open Access Publishing Group and European Journal of Economic and Financial Research shall not be responsible or answerable for any loss, damage or liability caused in relation to/arising out of conflict of interests, copyright violations and inappropriate or inaccurate use of any kind content related or integrated on the research work. All the published works are meeting the Open Access Publishing requirements and can be freely accessed, shared, modified, distributed and used in educational, commercial and non-commercial purposes under a Creative Commons Attribution 4.0 International License (CC BY 4.0). 